\title{
Alberta plans change in doctor compensation
}

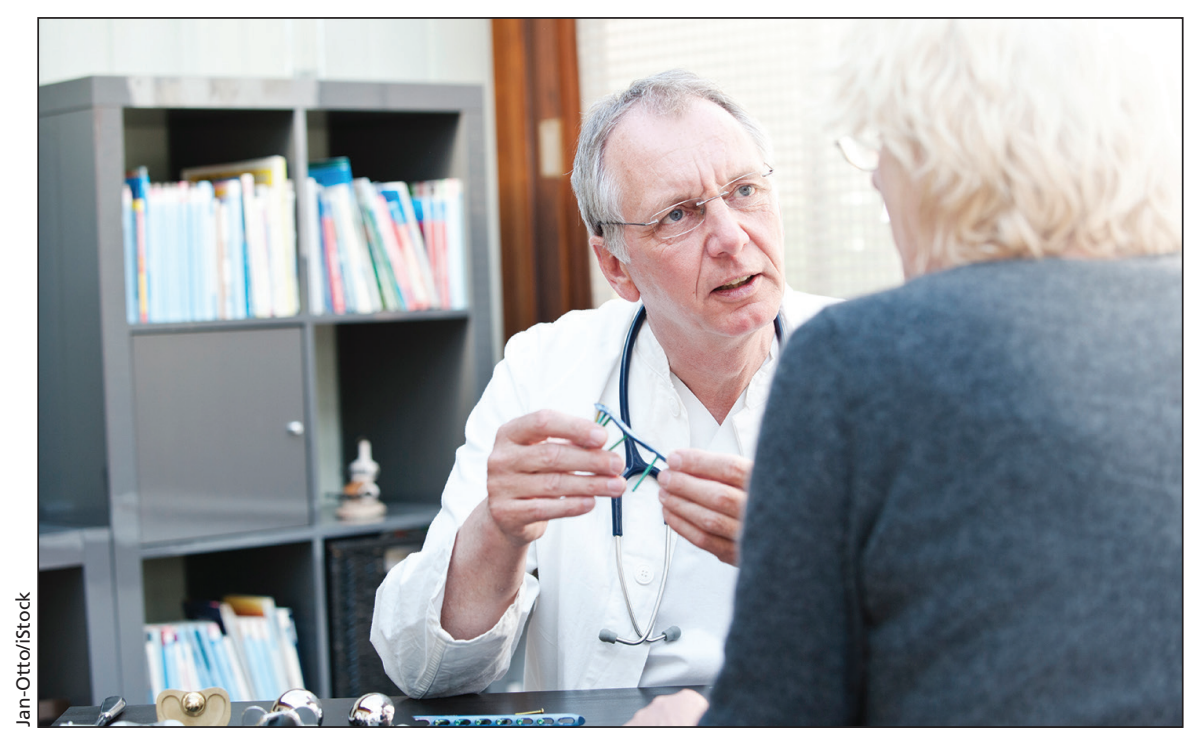

Doctors will have the chance to spend more time with patients under a new payment model in Alberta.

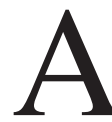
lberta plans to change how doctors are paid in a bid to curb spiraling costs and improve quality of care.

The current model for paying physicians is "expensive, outdated and doesn't support the efforts of doctors to provide the best care possible," said Health Minister Sarah Hoffman at a Feb. 8 policy forum in Edmonton on the health system's fiscal sustainability.

In 2014, Alberta spent $\$ 1060$ per capita on physician services - the third highest in the country. More than $80 \%$ of payments are through fee-forservice, where doctors bill the government for each medical service provided. Proponents of fee-for-service say it gives doctors the incentive to see as many patients and provide as many services as possible. Hoffman wants some of the doctors on fee-forservice to adopt Alternative Relationship Plans (ARP), which she said are not only less expensive, but also reward doctors for the quality of care they provide.

Under clinical ARPs, doctors are paid for providing a set of services at a facility to a target population. There are several types. The annualized ARP, the most common in Alberta, provides compensation based on a formula that determines the number of full-time equivalents (hours per year or days per year) required to deliver services.

In Ontario, the most common ARP is the capitation model, under which physicians are paid a fixed fee per month for each patient registered with their practices, regardless of services received.

The Alberta Medical Association (AMA), which represents the province's 8921 licensed physicians, supports the change. President Dr. Carl Nohr told CMAJ that ARPs are part of the move toward modernizing the health care system, which now deals with more chronic illness. They give doctors more flexibility, he said.

"They'll be able to vary the amount of time they spend with individual patients, define how frequently they see patients - all in the context of what's good for the patients and not necessarily from the business perspective."

Neither the AMA nor Hoffman could specify the number of doctors they want to adopt this model. Nohr said compensation under an ARP will remain optional, but "our goal is to make it as attractive as possible and make changes to the model as we go,

\section{Main physician payment models in Canada}

Fee-for-service: Physicians are paid a fixed fee for each service provided. This is the most prevalent model in Canada: about $40 \%$ of doctors receive almost all their income this way.

Blended model: A mixture of feefor-service, which makes up about $45 \%$ of a physician's income, and an Alternative Relationship Plan (ARP). About 33\% of Canadian physicians are paid under this model.

\section{Alternative Relationship Plans:}

An alternative mode of payment to fee-for-service.

\section{Alternative Relationship Plan models}

Capitation model: Physicians are paid a fixed fee per month for each patient registered with their practice, regardless of the service the patient has received.

Annualized model: Compensation is based on the number of physician full-time equivalents required to deliver the services.

Sessional model: Compensation is based on an hourly rate for the delivery of clinical services. This model applies to small, specialized programs and is intended for parttime participation.

Salaried model: Physicians are salaried employees of community health centres that provide care to a specific population.

Academic plans: A funding arrangement with physicians who teach or research at some universities or medical facilities. 
and hopefully over time see a substantial uptake."

Alberta's total health budget is $\$ 19.7$ billion for 2015-16 — the second highest per capita (\$4800) among the provinces. But, Hoffman said, "Given how much money is spent on health care in Alberta, the health outcomes in our province can and should be better."

Hoffman said health care accounts for $45 \%$ of the government's overall budget, and continues to grow faster than both inflation and the population, which grew $2.17 \%$ in 2015 . If health care spending continues to rise by an average of $6 \%$ annually, it will account for $60 \%$ of the province's budget in 20 years. Hoffman wants to decrease growth in health care spending to $2 \%$ annually in the next few years, but stressed this does not mean cutting funding; it means curbing spending growth.

Hoffman doesn't know how much will be saved by changing the physician compensation system, but said "changing the way we pay doctors will have a ripple effect on the entire health system."

The government's contract with the AMA expires in 2018, and both parties are discussing redirecting funds and developing alternative compensation models. Nohr said they're looking into a blend of ARP and fee-for-service among primary-care physicians.

"One of the very good things that gives me hope for the future is that the profession and the government have a very good relationship," Nohr said. "So there's a collaborative, positive relationship between the Alberta Medical Association and the Ministry of Health and that creates the possibility for productive, useful change." — Zoe Chong, CMAJ

CMAJ 2016. DOI:10.1503/cmaj.109-5240 